\title{
PEMANFAATAN KITOSAN UNTUK PENGENDALIAN BEAN COMMON MOSAIC VIRUS (BCMV) PADA KACANG PANJANG
}

\author{
Tri Asmira Damayanti, Haryanto, \& Suryo Wiyono \\ Departemen Proteksi Tanaman, Fakultas Pertanian Insitut Pertanian Bogor \\ Jl. Kamper, Kampus IPB Dramaga, Bogor 16680 \\ E-mail: triasmiradamayanti@gmail.com
}

\begin{abstract}
Utilization of chitosan to control Bean common mosaic virus (BCMV) on yard long bean. Bean common mosaic virus (BCMV) is one of important viruses infecting yard long bean in Indonesia. One of efforts to control its infection is by utilizing chitosan. Thus, the aim of the conducted research was to test the effectiveness of chitosan in controlling BCMV on yard long bean. Concentration of chitosan tested were $0.1 \%$ and $1.0 \%$ and it was applied as seed treatment (PB), leaf spraying before (SB) and after (ST) mechanical inoculation of BCMV. Incubation period, disease incidence and severity, peroxidase enzyme activity, and BCMV titer were measured as observation parameters. Incubation period of all treated plants were longer as compared with untreated control plants. Symptoms of treated plants at concentration $0.1 \%$ (SB and ST) showed mild to severe symptom and leaf malformation, while at concentration $1.0 \%$ showing milder symptoms and some of tested plants remain symptomless. Treated plants showed lower peroxidase enzyme activity and significantly lower BCMV titer as compared with that of untreated control plants. The lowest to highest percentage of virus inhibition exhibited by ST0.1, SB0.1, PB0.1, PB1, SB1 and ST1 treatments with virus relative inhibition level ranged $75.94 \%-86.07 \%$ and severity inhibition level ranged $39.55 \%$ $64.63 \%$.
\end{abstract}

Key words: BCMV, chitosan, yard long bean

\section{ABSTRAK}

Pemanfaatan kitosan untuk pengendalian Bean common mosaic virus (BCMV) pada kacang panjang. Bean common mosaic virus (BCMV) merupakan penyakit virus penting pada kacang panjang di Indonesia. Salah satu cara untuk mengendalikan BCMV adalah dengan penggunaan kitosan. Penelitian ini bertujuan untuk menguji keefektifan kitosan dalam mengendalikan BCMV pada kacang panjang. Konsentrasi yang digunakan $0.1 \%$ dan $1.0 \%$, dengan perlakuan benih (PB), perlakuan semprot daun sebelum (SB) dan perlakuan semprot setelah (ST) inokulasi mekanis BCMV, kontrol sehat dan kontrol tanpa perlakuan diinokulasi BCMV. Peubah pengamatan terdiri dari waktu inkubasi, gejala, kejadian dan keparahan penyakit, aktivitas enzim peroksidase, dan titer BCMV. Tanaman perlakuan kitosan menunjukkan waktu inkubasi yang nyata lebih panjang dibandingkan kontrol tanpa perlakuan. Pada konsentrasi kitosan $0.1 \%$ (SB dan ST) menunjukkan gejala mosaik ringan sampai berat serta malformasi daun, sedangkan perlakuan kitosan $1.0 \%$ menunjukkan gejala yang lebih ringan, dan beberapa tanaman uji tidak bergejala. Perlakuan kitosan menyebabkan aktivitas enzim peroksidase yang dan titer BCMV yang nyata lebih rendah dibandingkan kontrol tanpa perlakuan. Penghambatan virus terendah sampai tertinggi ditunjukkan oleh perlakuan ST0.1, SB0.1, PB0.1, PB1, SB1, dan ST1 dengan tingkat hambatan relatif (THR) virus sebesar 75.94\%-86.07\% dan THR keparahan $39.55 \%-64.63 \%$.

Kata kunci : BCMV, kacang panjang, kitosan

\section{PENDAHULUAN}

Pada tahun 2008 terjadi serangan berat penyakit mosaik kuning pada kacang panjang di Jawa. Salah satunya disebabkan oleh BCMV (Damayanti et al., 2009). Virus ini di lapangan ditularkan dan disebarkan oleh serangga vektor kutudaun dan terbawa benih dengan efisiensi yang tinggi (CABI, 2005), sehingga dengan karakter tersebut BCMV sulit untuk dikendalikan. Upaya pengendalian virus tanaman yang umum dilakukan adalah dengan menggunakan varietas yang tahan. Namun tidak banyak tersedia kultivar yang tahan BCMV. Setyastuti (2008) melaporkan bahwa dari 9 kultivar tanaman kacang panjang yang banyak ditanam oleh petani semua tergolong rentan terhadap BCMV.

Salah satu cara yang dapat digunakan dalam pengendalian patogen tanaman adalah dengan menginduksi ketahanan sistemik. Ketahanan sistemik 
tanaman dapat diaktifkan dengan menginduksi gen-gen ketahanan yang terdapat di dalam tanaman. Salah satu agens yang dapat menginduksi ketahanan sistemik tanaman adalah kitosan (Vasyukova et al., 2001).

Kitosan memiliki banyak kegunaan diantaranya sebagai bahan pengawet alami dan bahan kosmetik. Fragmen kitin dan kitosan dikenal memiliki aktifitas yang menginduksi berbagai respon pertahanan didalam tanaman terhadap infeksi mikroba seperti akumulasi fitoaleksin, PR (pathogenesis related) protein (glukanase, proteinase, peroksidase, ribonuclease like protein) dan proteinase inhibitor, sintesa lignin dan pembentukan kalus (Hadrami et al. 2010). Molekul kitosan memiliki toksisitas, dan menghambat perkembangan serta pertumbuhan fungi. Pelapisan kitosan dengan konsentrasi $2 \%$ pada buah mangga mampu menghambat perkembangan penyakit antraknosa (Wang et al., 2007). Kitosan dilaporkan mampu menekan infeksi Alfalfa mosaic virus (AMV), Cucumber mosaic virus (CMV), Tobacco necrosis virus (TNV), Tobacco mosaic virus (TMV), Peanut stunt virus (PSV), Potato virus $\mathrm{X}$ dan Potato spindle tuber viroid (PSTVd) (dirangkum dari Hadrami et al., 2010).

Mekanisme kerja kitosan dalam menghambat infeksi virus karena kitosan mampu menginaktivasi replikasi yang dapat menyebabkan terhentinya multiplikasi dan penyebaran virus. Selain itu nano partikel kitosan dapat mengikat asam nukleat pada saat virus melakukan penetrasi dan menyebabkan kerusakan pada virus. Kitosan juga dapat menonaktifkan sintesis mRNA yang dikodekan oleh gen untuk metabolik dan infeksi dari virus atau viroid (Rabea et al., 2003; Kulikov et al., 2006). Penghambatan Tobacco mosaic virus (TMV) oleh kitosan dilaporkan karena induksi ketahanan melalui deposisi kalose (callose deposition), micro-oxidative burst, respon hipersensitif mikro dan aktivitas antivirus yang terkait dengan produksi nitrit oksida dan aktivitas enzim phenylalanine amonia-lyase (PAL) (Iriti et al. 2006; Zhao et al., 2007). Aktivitas antivirus kitosan pada Tobacco necrosis virus (TNV) berkorelasi dengan kemampuan kitosan dalam menginduksi aposisi kalose (callose apposition) (Faoro \& Iriti, 2007).

Berdasarkan laporan-laporan tersebut, perlu dikaji potensi kitosan dalam menekan infeksi BCMV pada kacang panjang untuk mengatasi masalah penyakit ini. Oleh karena itu penelitian ini bertujuan untuk menguji efektifitas kitosan dalam mengendalikan penyakit mosaik pada kacang panjang yang disebabkan oleh BCMV di rumah kaca.

\section{METODE PENELITIAN}

Sumber Inokulum. Inokulum diambil dari kacang panjang bergejala mosaik dan positif terdeteksi dengan antiserum Potyvirus. Selanjutnya untuk mengisolasi BCMV dari virus lain yang kemungkinan menginfeksi bersama pada tanaman bergejala, BCMV dipisahkan pada tanaman indikator Chenopodium amaranticolor melalui inokulasi mekanis. Lesio lokal nekrotik (LLN) yang muncul diambil sebagai inokulum untuk diinokulasi berulang sebanyak tiga kali ke tanaman $C$. amaranticolor. LLN pada penularan terakhir diperbanyak pada tanaman kacang panjang. Deteksi molekuler dilakukan terhadap RNA total dengan RTPCR dan perunutan DNA. Hasil perunutan DNA gen parsial coat protein mengkonfirmasi bahwa inokulum yang digunakan adalah Bean common mosaic virus (data sekuen tidak ditampilkan).

Perbanyakan Inokulum Virus. Inokulum diperbanyak dengan menginokulasikan secara mekanis kacang panjang kultivar Parade berumur 7 hari setelah tanam (HST) dengan cairan tanaman sakit (sap). Inokulum digerus menggunakan mortar dan pistil steril bersama bufer fosfat dingin yang mengandung $1 \% \quad \beta$ mercaptoethanol (ditambahkan sebelum digunakan), dengan perbandingan inokulum dan bufer adalah 1:10 $(\mathrm{b} / \mathrm{v})$. Daun pertama kacang panjang ditaburi carborundum 600 mesh, lalu sap diinokulasi secara mekanis. Setelah diinokulasi daun dibilas dengan akuades.

Penanaman Kacang Panjang. Kacang panjang yang digunakan adalah kacang panjang kultivar Parade. Kacang panjang ditanam pada media tanam tanah dan pupuk kandang dengan perbandingan 2:1 di dalam polybag. Untuk setiap polybag ditanam 3 benih kacang panjang. Pada saat tanaman telah berumur 7 hari, dipilih satu tanaman dengan pertumbuhan paling baik. Pada umur 18 hari tanaman diberi ajir yang berguna untuk memudahkan tanaman tumbuh menjalar.

Pembuatan Larutan Kitosan. Konsentrasi kitosan yang digunakan pada penelitian ini adalah $0,1 \%$ dan $1 \%$. Kitosan diperoleh dari Laboratorium Teknologi Hasil Perikanan, Fakultas Perikanan dan Ilmu Kelautan IPB.

Perlakuan. Aplikasi kitosan dilakukan dalam bentuk perlakuan sebagai berikut: (1) Perlakuan kitosan 0,1\% pada benih (PB0,1), (2) Perlakuan kitosan 1\% pada benih (PB1), (3) Perlakuan kitosan 0,1\% sebelum inokulasi 
(SB0,1), (4) Perlakuan kitosan 1\% sebelum inokulasi (SB1), (5) Perlakuan kitosan $0,1 \%$ setelah inokulasi (ST0,1), (6) Perlakuan kitosan 1\% setelah inokulasi (ST1), (7) Tanpa perlakuan kitosan, tanaman diinokulasi dengan virus $(\mathrm{K}+)$, dan (8) Tanpa perlakuan kitosan, tanpa inokulasi virus/tanaman sehat (K-).

Perlakuan benih dilakukan dengan merendam benih kedalam larutan kitosan sesuai konsentrasi selama satu jam, perlakuan kitosan SB dilakukan pada saat tanaman berumur 5 HST (dua hari sebelum inokulasi BCMV), sedangkan perlakuan kitosan ST dilakukan pada saat tanaman berumur 9 HST (dua hari setelah inokulasi BCMV). Penyemprotan pada daun dilakukan merata keseluruh permukaan daun.

Inokulasi Tanaman Uji. Tanaman kacang panjang yang telah berumur 7 hari setelah tanam (HST) diinokulasi BCMV secara mekanis dengan metode seperti pada perbanyakan inokulum.

Perkembangan Penyakit. Parameter perkembangan penyakit yang diamati yaitu waktu inkubasi, kejadian penyakit, keparahan penyakit, dan titer virus yang dideteksi dengan Enzyme-linked immunosorbent assay (ELISA). Waktu inkubasi dihitung sejak inokulasi virus sampai munculnya gejala pertama yang dapat dilihat pada tanaman dan diamati hingga akhir penelitian.

Kejadian penyakit dihitung sebagai perbandingan jumlah tanaman sakit (n) terhadap total tanaman uji (N). Keparahan penyakit ditentukan dengan menggunakan skala berdasarkan gejala infeksi BCMV. Keparahan penyakit ditentukan pada saat tanaman berumur 2 dan 4 minggu setelah inokulasi. Adapun skala yang digunakan sebagai berikut (Gambar 1).

Tingkat hambatan relatif (THR) keparahan penyakit dihitung dengan rumus sebagai berikut.

$$
\text { THR Keparahan }=\frac{A-B}{A} \times 100 \%
$$

dengan:

THR = tingkat hambatan relatif,

$\mathrm{A}=$ skor keparahan penyakit $\mathrm{K}(+)$, dan

$\mathrm{B}=$ skor keparahan penyakit perlakuan.

Deteksi Serologi. Titer virus pada tanaman perlakuan ditentukan secara serologi dengan metode ACP-ELISA (Antigen coated-plate enzyme-linked immunosorbent assay) menggunakan antiserum Potyvirus (DSMZ). Prosedur yang digunakan sesuai dengan manual pembuatnya (DSMZ, Jerman). Nilai Absorbansi ELISA (NAE) adalah nilai absorbansi virus untuk mendapatkan gambaran kuantitatif virus yang terdapat pada setiap tanaman perlakuan. Selain itu NAE dapat digunakan untuk konfirmasi kejadian penyakit pada tiap perlakuan. Kuantifikasi NAE dilakukan dengan menggunakan ELISA Reader pada panjang gelombang $405 \mathrm{~nm}$. Uji dinyatakan positif jika NAE sampel besarnya 2 kali NAE kontrol sehat.

Tingkat hambatan relatif virus karena perlakuan kitosan ditentukan dengan rumus sebagai berikut.

$$
\text { THR virus }=\frac{A-B}{A} \times 100 \%
$$

dengan:

THR = tingkat hambatan relatif,

$\mathrm{A}=$ rata-rata $\mathrm{NAE} \mathrm{K}(+)$, dan

$\mathrm{B}=$ rata-rata NAE perlakuan.

Penentuan Aktivitas Enzim Peroksidase (PO). Untuk mengetahui perlakuan kitosan menginduksi ketahanan sistemik tanaman atau tidak, dilakukan pengukuran aktivitas enzim peroksidase. Sumber enzim
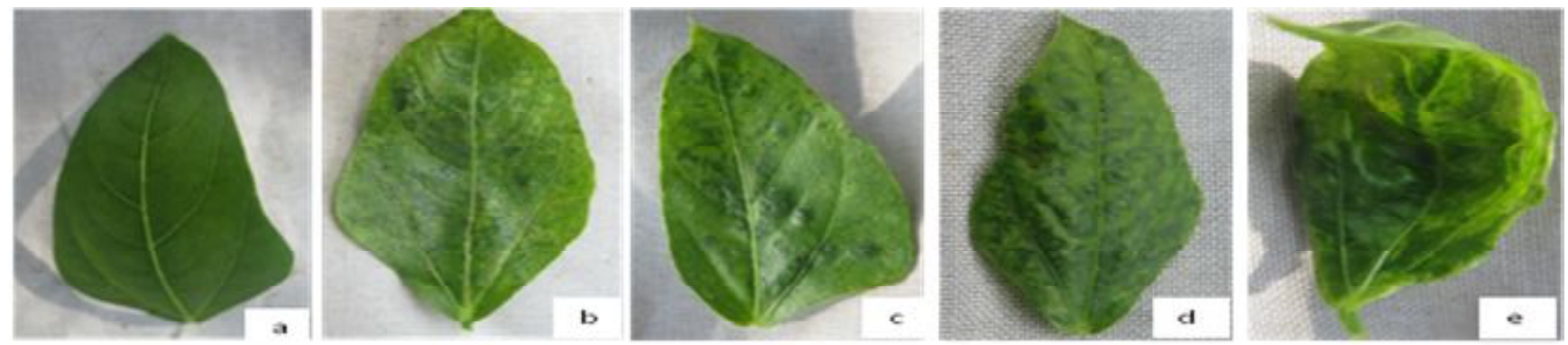

Gambar 1. Skala untuk keparahan penyakit. (a) Skor 0 (tanaman tidak menunjukkan gejala), (b) skor 1 (gejala mosaik ringan disertai pemucatan tulang daun, (c) skor 2 (gejala mosaik sedang), (d) skor 3 (gejala mosaik berat), dan (e) skor 4 (gejala mosaik berat dengan malformasi daun yang parah, kerdil, atau mati). 
diekstraksi dari daun perlakuan yang diambil pada 1 minggu setelah inokulasi BCMV. Aktivitas enzim peroksidase ditentukan dengan metode yang digunakan oleh Hammerschmidt et al. (1982).

Analisis Data. Percobaan ini disusun dalam Rancangan acak lengkap (RAL) terdiri dari 8 perlakuan dengan masing-masing perlakuan 9 tanaman uji sebagai ulangan. Data diolah dengan analisis ragam (ANOVA) dan dilanjutkan dengan uji selang berganda Duncan (DMRT) pada taraf nyata $\alpha=5 \%$ menggunakan SAS versi 6.12.

\section{HASIL DAN PEMBAHASAN}

Pengaruh Perlakuan Kitosan terhadap Waktu Inkubasi. Tanaman yang diberi kitosan dengan konsentrasi dan waktu perlakuan yang berbeda memiliki waktu inkubasi yang nyata lebih lama dibandingkan dengan tanaman tanpa kitosan, namun antar perlakuan kitosan tidak menimbulkan perbedaan waktu inkubasi yang signifikan. Waktu inkubasi yang dibutuhkan virus untuk menunjukkan gejala pada tanaman kontrol tanpa perlakuan rata-rata 4.66 hari. Sedangkan waktu inkubasi tanaman yang diberi perlakuan kitosan rata-rata 6.67.8 hari (Tabel 1). Hal ini menunjukkan bahwa perlakuan kitosan memperpanjang waktu inkubasi.

Pengaruh Perlakuan Kitosan terhadap Gejala. Gejala infeksi BCMV pada tanaman perlakuan beragam. Pada tanaman kontrol tanpa perlakuan $(\mathrm{K}+)$, gejala yang muncul berupa mosaik berat, malformasi daun, dan kerdil, sedangkan untuk setiap perlakuan kitosan gejala yang muncul adalah mosaik ringan, mosaik sedang, mosaik berat, dan malformasi daun tergantung pada jenis perlakuan. Perbedaan konsentrasi dan waktu aplikasi yang dilakukan menimbulkan respon yang berbeda pada tanaman. Pada perlakuan kitosan $1 \%$ (PB1, SB1, ST1) gejala yang tampak yaitu mosaik ringan hingga sedang. Namun pada perlakuan kitosan 0,1\% (PB0,1, SB0,1, ST0,1) gejala yang tampak yaitu mosaik berat bahkan malformasi daun. Dari data ini terlihat bahwa gejala tanaman yang diberi perlakuan kitosan $1 \%$ lebih ringan dibandingkan dengan perlakuan kitosan $0,1 \%$ dan kontrol tanpa perlakuan $(\mathrm{K}+)$ (Tabel 1).

\section{Pengaruh Perlakuan Kitosan terhadap Kejadian dan Keparahan Penyakit serta Aktivitas Enzim Peroksidase. Beberapa tanaman yang diberi perlakuan kitosan menunjukkan tidak terserang oleh BCMV meskipun telah diinokulasi secara mekanis. Kejadian penyakit perlakuan kitosan $1 \%$ dengan waktu aplikasi yang berbeda (PB1, SB1 dan ST1) menunjukkan 3 dari 9 tanaman yang diinokulasi tidak terinfeksi BCMV. Kejadian penyakit perlakuan kitosan $0,1 \%$ dengan waktu aplikasi yang berbeda (PB0,1, SB0,1 dan ST0,1) menunjukkan 2 dari 9 tanaman yang diinokulasi tidak terinfeksi BCMV (Tabel 1). Kitosan 1\% menunjukkan lebih menekan BCMV dibandingkan dengan kitosan $0,1 \%$.}

Tabel 1. Pengaruh perlakuan terhadap waktu inkubasi virus dan gejala

\begin{tabular}{lccc}
\hline Perlakuan $^{\mathrm{a}}$ & $\mathrm{KP}(\mathrm{n} / \mathrm{N})(\%)^{\mathrm{b}}$ & ${\text { Waktu Inkubasi }\left(\mathrm{HSI}^{\circ}\right)}$ & Gejala $^{\mathrm{f}}$ \\
\hline K- & $0 / 9$ & $-^{\mathrm{e}}$ & Tidak ada gejala $^{\mathrm{a}}$ \\
K+ & $9 / 9$ & $4,66 \pm 0.50 \mathrm{~b}^{\mathrm{d}}$ & $\mathrm{Mb}, \mathrm{Md}, \mathrm{K}$ \\
PB 0,1 & $7 / 9$ & $6,60 \pm 1.21 \mathrm{a}$ & $\mathrm{Mr}, \mathrm{Mb}, \mathrm{Md}$ \\
PB 1 & $6 / 9$ & $7,00 \pm 0.89 \mathrm{a}$ & $\mathrm{Mr}, \mathrm{Ms}$ \\
SB 0,1 & $7 / 9$ & $7,20 \pm 1.60 \mathrm{a}$ & $\mathrm{Mr}, \mathrm{Ms}, \mathrm{Md}$ \\
SB 1 & $6 / 9$ & $7,75 \pm 1.14 \mathrm{a}$ & $\mathrm{Mr}$ \\
ST 0,1 & $7 / 9$ & $7,40 \pm 0.95 \mathrm{a}$ & $\mathrm{Mr}, \mathrm{Mb}$ \\
ST 1 & $6 / 9$ & $7,80 \pm 1.21 \mathrm{a}$ & $\mathrm{Mr}, \mathrm{Ms}$ \\
\hline
\end{tabular}

${ }^{a}$ K- : Kontrol sehat; K+ : Kontrol terinfeksi BCMV tanpa perlakuan; PB0,1 : Perlakuan benih dengan kitosan $0,1 \%$; PB1 : Perlakuan benih dengan kitosan 1\%; SB0,1: Perlakuan sebelum inokulasi dengan kitosan 0,1\%; SB1: Perlakuan sebelum inokulasi dengan kitosan 1\%; ST0,1 : Perlakuan setelah inokulasi dengan kitosan 0,1\%; ST1 : Perlakuan setelah inokulasi dengan kitosan $1 \%$.

b KP:kejadian penyakit =n/ $\mathrm{N}$ dimana $\mathrm{n}$-jumlah tanaman bergejala, $\mathrm{N}$-jumlah tanaman uji

${ }^{\mathrm{c}}$ HSI : Hari setelah inokulasi

d angka yang diikuti huruf yang sama dalam kolom yang sama menunjukkan tidak berbeda nyata menurut uji Duncan $\alpha=0,05$

$\mathrm{e}_{-}=$tidak ada 
Perlakuan kitosan dengan konsentrasi 0,1\% dan $1 \%$ serta waktu aplikasi yang berbeda menunjukkan mampu menekan keparahan penyakit oleh BCMV bila dibandingkan dengan kontrol tanaman sakit tanpa perlakuan kitosan $(\mathrm{K}+)$ (Tabel 2). Perlakuan kitosan 1\% (PB1, SB1, ST1) menunjukkan keparahan penyakit yang lebih rendah bila dibandingkan dengan perlakuan kitosan $0,1 \%$ maupun kontrol tanaman yang diinokulasi virus $(\mathrm{K}+)$ pada pengamatan 4 minggu setelah inokulasi. Adanya perbedaan konsentrasi sangat berpengaruh terhadap kemampuan menghambat infeksi BCMV. Kitosan $1 \%$ lebih menekan keparahan penyakit dibandingkan perlakuan kitosan $0,1 \%$.

Tingkat hambatan relatif pada perlakuan kitosan 1\% (PB1, SB1, dan ST1) lebih tinggi jika dibandingkan dengan kontrol tanaman yang diinokulasi dengan virus $(\mathrm{K}+)$ dan perlakuan kitosan lainnya yaitu sebesar $57,23 \%-64,63 \%$, sedangkan tingkat hambatan relatif perlakuan kitosan $0,1 \%$ lebih rendah yaitu berkisar antara 39,55\%-43,09\% (Tabel 2).

NAE semua perlakuan kitosan dengan konsentrasi dan waktu aplikasi yang berbeda memiliki nilai yang nyata lebih rendah jika dibandingkan dengan NAE kontrol tanpa perlakuan yang diinokulasi BCMV (Tabel 2). Titer virus pada perlakuan SB1 dan ST1 menunjukkan NAE yang nyata lebih rendah bila dibandingkan dengan kontrol tanpa perlakuan dan perlakuan kitosan lainnya. Hal ini mungkin disebabkan konsentrasi kitosan yang digunakan $1 \%$ dan waktu aplikasinya sebelum dan sesudah inokulasi BCMV lebih tepat bila dibandingkan dengan perlakuan lainnya.
Kemampuan kitosan 0,1\% (PB0,1 dan SB0,1) dan $1 \%$ (PB1, SB1 dan ST1) dalam menghambat virus cukup tinggi. Semua perlakuan kitosan menunjukkan penghambatan virus lebih dari $80 \%$, kecuali perlakuan ST0,1 (75.94\%) (Tabel 2).

Aktivitas enzim peroksidase tanaman kacang panjang yang diberi perlakuan lebih rendah dibandingkan dengan tanaman kontrol tanpa perlakuan yang diinfeksi BCMV. Aktivitas enzim peroksidase pada perlakuan PB1, SB0,1, SB1, dan ST0,1 bahkan lebih rendah dari pada kontrol sehat (Gambar 2). Hal ini menunjukkan bahwa induksi ketahanan yang ditunjukkan oleh kitosan diduga tidak melalui peningkatan aktivitas enzim peroksidase, namun melalui mekanisme lain yang perlu diteliti lebih lanjut. Infeksi virus yang ditularkan secara mekanis melalui luka akan menimbulkan kondisi stres pada tanaman dan meningkatkan aktifitas enzim peroksidase dalam beberapa hari setelah diinokulasi, dan semakin meningkat sampai tanaman menunjukkan gejala. Pada tanaman yang toleran, aktifitas enzim peroksidase tidak meningkat setelah diinokulasi virus (Riedle-Bauer, 1997). Senyawa kitosan yang masuk melalui stomata merupakan penentu mekanisme pertahanan tanaman terhadap TNV. Kitosan menginduksi ketahanan tanaman terhadap TNV melalui aposisi kalose (callose apposition) dan meningkatkan produksi etilen (Faoro \& Iriti, 2007; Iriti et al., 2010). Terhadap TMV, kitosan menginduksi ketahanan melalui deposisi kalose (callose deposition), micro-oxidative burst, respon hipersensitif mikro dan aktivitas antivirus yang terkait dengan produksi nitrit oksida dan aktivitas

Tabel 2. Pengaruh perlakuan terhadap keparahan penyakit dan titer virus

\begin{tabular}{llccc}
\hline Perlakuan $^{\mathrm{a}}$ & Keparahan $^{\mathrm{b}}(\%)$ & THR Keparahan $(\%)$ & NAE $^{\mathrm{c}}$ & THR Virus (\%) $^{\text {K }}$ \\
\hline K- & $0,00 \pm 0,00 \mathrm{c}$ & 100,00 & $0,13 \pm 0,01 \mathrm{a}$ & 100,00 \\
K+ & $3,11 \pm 0,19 \mathrm{a}$ & 0,00 & $2,37 \pm 0,56 \mathrm{e}$ & 0,00 \\
PB 0,1 & $1,77 \pm 0,69 \mathrm{~b}$ & 43,09 & $0,42 \pm 0,12 \mathrm{~b}$ & 82,27 \\
PB 1 & $1,33 \pm 0,67 \mathrm{~b}$ & 57,23 & $0,42 \pm 0,20 \mathrm{c}$ & 82,27 \\
SB 0,1 & $1,77 \pm 0,19 \mathrm{~b}$ & 43,09 & $0,43 \pm 0,16 \mathrm{~cd}$ & 81,85 \\
SB 1 & $1,11 \pm 0,19 \mathrm{bc}$ & 64,31 & $0,36 \pm 0,21 \mathrm{~b}$ & 84,81 \\
ST 0,1 & $1,88 \pm 0,76 \mathrm{~b}$ & 39,55 & $0,57 \pm 0,19 \mathrm{~d}$ & 75,94 \\
ST 1 & $1,10 \pm 0,69 \mathrm{bc}$ & 64,63 & $0,33 \pm 0,20 \mathrm{~b}$ & 86,07 \\
\hline
\end{tabular}

${ }^{a}$ K- : Kontrol sehat; K+: Kontrol terinfeksi BCMV tanpa perlakuan; PB0.1: Perlakuan benih dengan kitosan 0,1\%; PB1 : Perlakuan benih dengan kitosan 1\%; SB0,1 : Perlakuan sebelum inokulasi dengan kitosan 0,1\%; SB1 : Perlakuan sebelum inokulasi dengan kitosan 1\%; ST0,1 : Perlakuan setelah inokulasi dengan kitosan 0,1\%; ST1 : Perlakuan setelah inokulasi dengan kitosan $1 \%$.

${ }^{\mathrm{b}}$ angka yang diikuti huruf yang sama dalam kolom yang sama menunjukkan tidak berbeda nyata menurut uji Duncan $\alpha=0,05$

c NAE: Nilai absorban ELISA. 


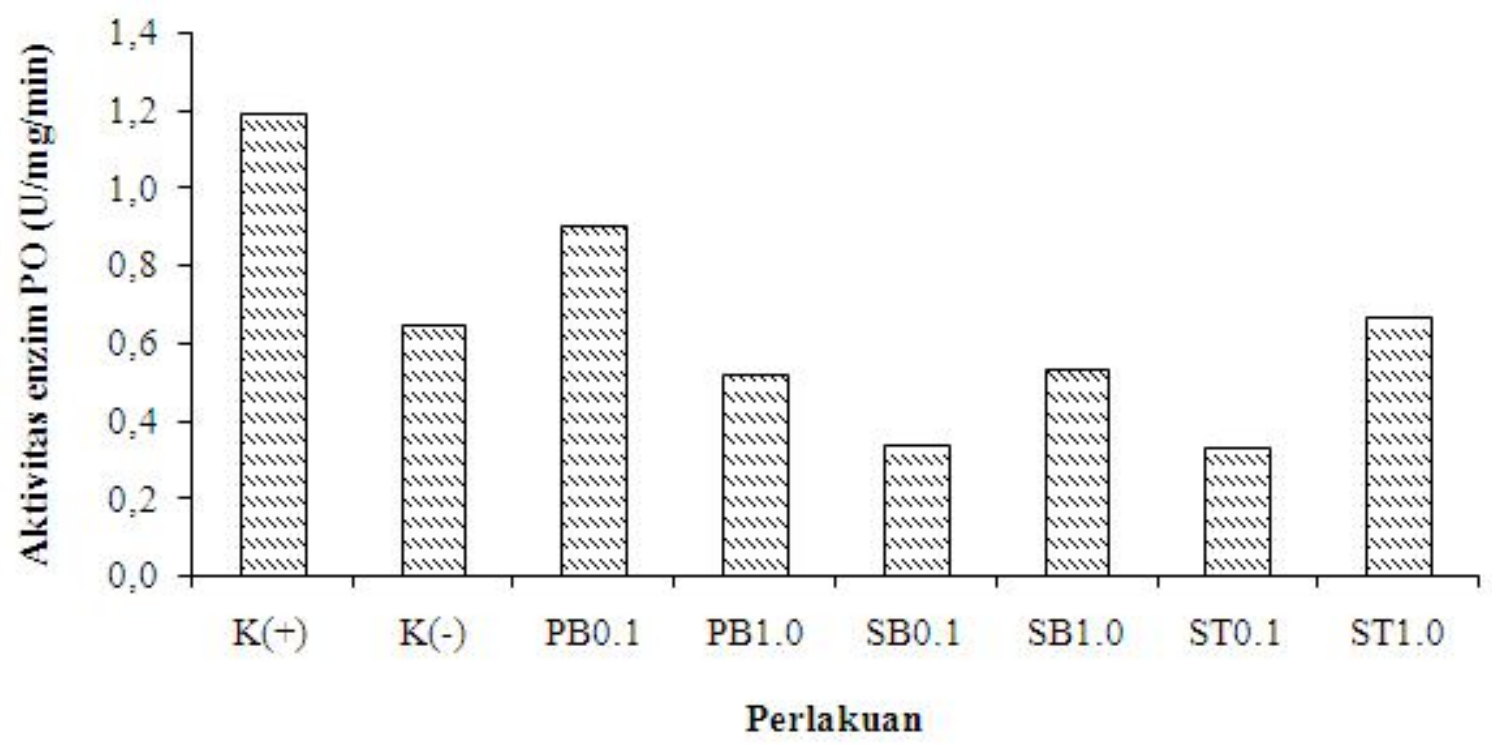

Gambar 2. Aktivitas enzim peroksidase (PO) (U/mg/min) tiap perlakuan pada 1 MSI. PO diukur kumulatif dari semua tanaman tiap perlakuan.

enzim phenylalanine amonia-lyase (PAL) pada TMV (Iriti et al., 2006; Zhao et al., 2007).

Kitosan dilaporkan memiliki potensi meningkatkan ketahanan tanaman terhadap stres pada tanaman Brassica napus dengan menginduksi produksi nitrit oksida dan hidrogen peroksida (Li et al., 2009). Kitosan dan Bacillus thuringiensis dalam bentuk perlakuan tunggal atau campuran menunjukkan dapat meningkatkan ketahanan tanaman terhadap infeksi BCMV pada buncis and kutudaun vektornya (Faoro, 2013). Selain itu kitosan dilaporkan mampu meningkatkan perkecambahan dan toleransi garam (salt-tolerance) pada bibit padi hibrida (Ruan \& Xue, 2002), Brassica napus (Wang et al., 2012) dan meningkatkan ketahanan tanaman terhadap stres kekeringan pada padi (Pongprayoon et al.,2013). Berdasarkan laporan-laporan tersebut diatas dan penelitian ini menunjukkan bahwa perlakuan kitosan dapat meningkatkan ketahanan tanaman terhadap stres karena faktor biotik (infeksi patogen) dan meningkatkan toleransi oleh faktor abiotik.

Kitosan memiliki kemampuan dalam menekan kejadian penyakit dan keparahan penyakit serta titer BCMV. Perbedaan konsentrasi kitosan yang digunakan berpengaruh terhadap parameter perkembangan penyakit. Selain itu secara umum pertumbuhan tanaman yang diberi perlakuan kitosan lebih baik dibandingkan tanaman kontrol tanpa perlakuan (data tidak ditampilkan). Tanaman yang diberi perlakuan kitosan $1 \%$ memiliki titer BCMV yang nyata lebih rendah, dengan
THR virus dan keparahan penyakit yang tinggi bila dibandingkan dengan perlakuan kitosan $0,1 \%$ dan kontrol tanaman sakit tanpa perlakuan kitosan. Hal ini menunjukkan bahwa perlakuan kitosan $1 \%$ lebih baik dalam menekan infeksi BCMV. Keefektifan kitosan dalam menghambat infeksi virus tergantung pada kombinasi inang-virus, konsentrasi kitosan dan metode aplikasi (Hadrami et al., 2010)

Kitosan dapat menonaktifkan sintesis mRNA virus dan viroid, mampu menginaktivasi replikasi yang dapat menyebabkan terhentinya multiplikasi dan penyebaran virus. Selain itu nano partikel kitosan juga dapat mengikat asam nukleat pada saat virus melakukan penetrasi dan menyebabkan kerusakan pada virus (Kulikov et al., 2006). Jika dilihat titer BCMV pada semua perlakuan yang nyata lebih rendah dibandingkan dengan kontrol tanpa perlakuan, diduga perlakuan kitosan mengganggu atau merusak asam nukleat virus, namun perlu penelitian lebih lanjut untuk membuktikannya.

\section{SIMPULAN}

Kitosan dengan konsentrasi $1 \%$ sebagai perlakuan benih (PB1), penyemprotan tanaman sebelum inokulasi (SB1) dan penyemprotan tanaman setelah inokulasi (ST1) lebih efektif dalam mengendalikan BCMV. Kitosan konsentrasi 1\% menunjukkan kejadian dan keparahan penyakit, aktivitas enzim peroksidase serta titer BCMV nyata lebih rendah bila dibandingkan dengan kitosan konsentrasi $0,1 \%$. 


\section{DAFTAR PUSTAKA}

Central for Agricultural and Bioscience International [CABI]. 2005. Crop protection compendium [CD-ROM]. Wallingford: CAB International.

Damayanti TA, Alabi OJ, Naidu RA, \& Rauf A. 2009. Severe Outbreak of a yellow mosaic disease on the yard long bean in Bogor, West Java. HAYATI J. Biosci, 16: 78-82.

Faoro F \& Iriti M. 2007. Callose synthesis as a tool to screen chitosan efficacy in inducing plant resistance to pathogens. Caryologia, 60: 121124

Faoro F. 2013. Induced systemic resistance against systemic viruses: a feasible approach?. IOBCWPRS Bul. 89: 199-203.

Hadrami AE, Adam LR, Hadrami EI, \& Daayf F. 2010. Chitosan in plant protection. Marine Drugs, 5: 968-987

Hammerschmidt R, Nuckles EM, \& Kuc J. 1982. Association of enhanced peroxidase activity with induced systemic resistance of cucumber to Colletotrichum lagenarium. Physiol Plant Pathol, 20: 73-82.

Iriti M, Castorina G, Vitalini S, Mignani I Soave C, Fico G, \& Faoro F. 2010. Chitosan-induced ethyleneindependent resistance does not reduce crop yield in bean. Biol Control, 54: 241-247.

Iriti M, Sironi M, Gomarasca S, Casazza AP, Soave C, \& Faoro F. 2006. Cell death mediated antiviral effect of chitosan in tobacco. Plant Physiol Biochem, 44: 893-900

Kulikov SN, Chirkov SN, Il'ina AV, Lopatin SA, \& Varlamov VP. 2006. Effect of the molecular weight of chitosan on its antiviral activity in plants. App. Biochem. Microbiol 42(2): 200-203.

Li Y, Yin H, Wang Q, Zhao X, DU Y, \& Li F. 2009. Oligochitosan induced Brassica napus L production of $\mathrm{NO}$ and $\mathrm{H} 2 \mathrm{O} 2$ and their phisiological function. Carbohydrate Polymers 75(4): 612617.
Pongprayoon W, Roytrakul S, Pichayangkura R, \& Chadchawan S. 2013. The role of hydrogen peroxide in chitosan-induced resistance to osmotic stress in rice (Oryza sativa L.). Plant Growth Regulation 70 (2): 159-173.

Rabea EI, Badawy MET, Steven CV, Smagghe G, \& Steurbaut W. 2003. Chitosan as antimicrobial agent: application and mode of action. Biomacromolecules 4(6): 1457-1465.

Riedle-Bauer M. 1997. Activities of antioxidant enzymes in cucumber plants infected with cucumber mosaic virus. Phyton, 38: 149-157

Ruan SL \& Xue QZ. 2002. Effects of chitosan coating on seed germination and salt-tolerance of seedlings in hybrid rice (Oryza sativa L.). Acta Agron Sinica, 28: 803-808.

Setyastuti L. 2008. Tingkat ketahanan sembilan kultivar kacang panjang terhadap infeksi Bean common mosaic virus (BCMV) [Skripsi]. Fakultas Pertanian, Institut Pertanian Bogor.

Vasyukova NI, Zinov'eva SV, ll'inskaya LI, Perekhod EA, Chalenko GI, Gerasimova NG, ll'ina AV, Varmalov VP, \& Ozeretskovskaya OL. 2001. Modulation of plant resistance to desease by water-soluble chitosan. App Biochem Microbiol, 37(1): 103-109.

Wang J, Wang B, Jiang B, \& Zhao Y. 2007. Quality and shelf life of mango (Mangifera indica $1 . \mathrm{cv}$. 'Tainong') coated by using chitosan and polyphenols. SAGE Publications. Food Sci Tech Int 13(4): 317-322.

Wang YJ, Wang MY, \& Huang RR. 2012. Effect of Chitosan Coating on Seed Germination and Salttolerance of Brassica napus L. Bulletin of Botanical Research 32(6): 689-694

Zhao XM, She XP, Yu W, Liang XM, \& Du YG. 2007 Effects of oligochitosans on tobacco cells and role of endogenous nitric oxide burst in the resistance of tobacco to TMV. J. Plant Pathol, 89: 55-65. 